DOI 10.37882/2223-2982.2020.09.40

\title{
ВОЕННО-ПОЛИТИЧЕСКАЯ СТРАТЕГИЯ ИМПЕРАТОРА ФЕОДОСИЯ I В СЕВЕРНОМ ПРИЧЕРНОМОРЬЕ
}

\section{MILITARY AND POLITICAL STRATEGY OF EMPEROR THEODOSIUS I IN THE NORTHERN BLACK SEA REGION}

\section{S. Yartsev}

Summary: The article deals with the complex topic of the military and political strategy of Emperor Theodosius I in the Northern Black Sea region. Based on a thorough study of the sources, the author offers a new concept of the history of the region in the 80 's of 4th century AD, in the context of the foreign policy of the Roman Empire. According to the researcher, the close relations with the Huns established by Theodosius I indicate the Emperor's desire to restore the buffer zone of the Roman Empire, consisting of nomad hordes and dependent agricultural Gothic population, in the Northern Black Sea region. At the same time, it is possible that the submission of the settled population to the North of the Lower Danube by the Huns could have been sanctioned by the Romans and have been a kind of compensation to the nomads for the loss of a part of their dependent agricultural population during the treaty with the Goths in 382. In order to prevent the Huns from uniting into one powerful force and perhaps for the purpose of contrasting different groups of barbarians with each other, a strictly differentiated policy was applied to them. Relations with the Western Huns were established in the areas of the Danube Limes while the Romans' contacts with the Eastern nomads were taking place in the Bosporan Tanais. The restored buffer zone passed the test of strength when the usurper Maximus managed to provoke the Goths of the Northern Black Sea region into making a speech against Theodosius I. At the same time, it is obvious that Maximus did not overlook the Bosporus as well as the barbarians who lived on the perimeter of its borders. Probably, the destruction layers of the end of the 4th century $A D$, known in the Bosporus, were relevant not to the attack of the Huns in 395 but to the events of the 80 s of 4th century AD. What is more there is a possibility that at that time the Bosporus state administration reorganization happened and included the promotion of noble Huns and Alans to high positions which could be a kind of payment to the allied barbarians for help in suppressing the rebellion.

Keywords: Roman Empire, Bosporan Kingdom, Northern BlackSea region, Emperor Theodosius I, Emperor Maximus, Goths, Huns.
Ярцев Сергей Владимирович

Д.и.н., доцент, Тульский государственный педагогический университет им. Л.Н. Толстого

s-yartsev@yandex.ru

Аннотация: Статья посвящена сложной теме военно-политической стратегии императора Феодосия I в Северном Причерноморье. На основе тщательного изучения источников, автор предлагает новую концепцию истории региона в 80-х гг. IV в. н.э., в контексте внешней политики Римской империи. По мнению исследователя, установленные Феодосием I тесные отношения с гуннами, свидетельствуют о стремлении императора восстановить буферную зону Римской империи в Северном Причерноморье, состоящую из орд кочевников и зависимого от них земледельческого готского населения. При этом возможно, что подчинение гуннами оседлого населения к северу от Нижнего Дуная, могло быть санкционировано римлянами и являться своеобразной компенсацией кочевникам за потерю части своего зависимого земледельческого населения в ходе договора с готами 382 года. Для того же, чтобы не дать гуннам соединиться в одну мощную силу, а возможно еще и с целью противопоставления друг другу различных групп варваров, по отношению к ним, проводилась строго дифференцированная политика. С западными гуннами были налажены отношения в районах Дунайского лимеса, контакты же римлян с восточными кочевниками происходили в боспорском Танаисе. Испытание на прочность, восстановленная буферная зона прошла, когда узурпатору Максиму удалось подбить на выступление против Феодосия I, готов Северного Причерноморья. При этом очевидно, что Максим, не обошел вниманием и Боспор, а также варваров, живших по периметру его границ. Возможно, слои разрушения конца IV в. н.э., известные на Боспоре, имеют отношение не к нападению гуннов в 395 году, а к событиям 80-х гг. IV в. н.э. Также, не исключено, что именно в это время, была проведена реорганизация государственного управления Боспора с выдвижением на высокие должности знатных гуннов и аланов, которая могла являться своеобразной платой союзным варварам, за помощь в подавлении мятежа.

Ключевые слова: Римская империя, Боспорское царство, Северное Причерноморье, император Феодосий I, император Максим, готы, гунны.
$\mathrm{P}$ анее мы уже говорили об изменениях римской военно-политической стратегии в Северном Причерноморье при Юлиане. Буквально за короткий срок правления этого императора здесь была восстановлена эшелонированная буферная зона, состоящая из античных центров, варварского оседлого населения и союзных гуннских орд, недавно появившихся в регионе [34, с. 217-244]. После этого, император Валент скорректиро- вал данные планы из-за обострения отношений с готами. Новой стратегической целью в Северном Причерноморье теперь, по-видимому, стало превращение всех готов в зависимое от римских властей земледельческое население, ориентированное на античные центры [34, с. 250]. Правда здесь Валент недооценил силы готов, которые, несмотря на поражение от гуннов, смогли осуществить вторжение на территорию империи и нанести со- 
крушительный разгром римской армии [34, с. 273-284]. При этом римлянами были слабо учтены интересы самих гуннов, которые вряд ли могли довольствоваться только организацией с ними товарообмена в районах античных центров Северного Причерноморья. Торговые контакты с римским миром действительно являлись основным источником поступления к кочевникам оружия, одежды, зерна и предметов роскоши [25, с. 205-212]. Однако гуннов не мог также не интересовать самостоятельный источник продовольствия, приток которого, как правило, осуществлялся от находящихся в подчинении оседлых земледельцев. Поэтому, не исключено, что Валент в случае покорения готов, мог обещать своим союзникам восточную часть данного населения, причем в качестве рабов или людей напоминающих по статусу римских колонов.

Последующие военные действия римлян и гуннов с готами при императорах Грациане и Феодосии I, безусловно, способствовали дальнейшему развитию римскогуннских отношений. Борьба с общим врагом, безусловно, сыграла свою роль в принятии Грацианом решения о заключении союза с варварской группировкой, значительную часть которой занимали гунны. При этом данные выходцы из Северного Причерноморья, расселенные в 380 году в Паннонии [Jord. Get., 141], скорее всего, уже изначально являлись союзниками римлян, находясь на стороне гуннов, готов Гуннимунда и боспорских варваров [34, с. 270-271]. Конечно, сейчас трудно понять, что это были за гунны и поддерживали ли они связь со своими соплеменниками, оставшимися в причерноморских степях. Скорее всего, уже с этого времени разные группы кочевников, не будучи еще объединенные единой властью, приступили к разделу завоеванной северопричерноморской территории на сферы влияния и зоны хозяйственной деятельности. Вследствие этого, варвары начали концентрироваться в нескольких районах, известных нам по археологическим памятникам гуннского периода $[9 ; 35 ; 36 ; 41 ; 43 ; 44]$. Не так давно этот археологический материал был проанализирован М.М. Казанским и А.В. Мастыковой. Ученые выявили в регионе две археологические зоны гуннских находок, с границей между ними по реке Днепр и Приазовью. Западная зона включала в себя причерноморские степи к западу от Днепра, в том числе районы Молдавии и Валахии, восточная - степи Нижнего Дона, Северного Кавказа, Поволжья и земли Южного Приуралья. При этом степи Приазовья и Крыма, расположенные между двумя этими зонами, находки гуннского времени содержали очень мало [14, с. 114]. Возможно, причиной этого является, более позднее освоение данных районов гуннами, по сравнению с землями основных зон и недостаточное количество водных ресурсов на данной территории. Однако заметим, что, судя по археологическому материалу, кочевники двух зон, оставившие нам указанные памятники, отличались друг от друга своими культурными традициями. Наряду с общераспространенными во всем гуннском мире ингу- мациями в грунтовых могилах, в ямах с подбоями, жертвоприношениями коней, обычаем помещения шкуры лошади в могиле и конского снаряжения, учеными были выявлены и некоторые специфические особенности каждой из таких гуннских археологических территорий. Так, для восточной группы гуннов были характерны трупосожжения [9, с. 19-20], в том числе и под курганами [9, с. 12-13; 41, р. 122], захоронения в гротах [9, с. 187-188], в античных склепах [9, с. 177-180], в деревянных гробах [41, р. 122], при этом ориентированные головой на восток или на запад/юго-запад [14, с. 119-120]. Встречаются здесь и так называемые курганы «с усами» [14, с. 119], которые, несмотря на всю сложность датировки, безусловно, имеют непосредственное отношение и к гуннской эпохе [5, с. 103-117]. М.М. Казанским и А.В. Мастыковой восточная зона распространения гуннских археологических памятников вполне обосновано была отождествлена с акацирами [Prisc., 8], а западная с ордами Харатона, Доната и Ульдиса. Последние варвары также связываются с альмидзурами/альпидзурами, упомянутыми Приском [Prisc., 1] [14, с. 123-124].

Тем не менее, несмотря на все известные нам данные, уточнить время, когда гунны вплотную подступили к границам Римской империи, не просто. Мало в этом может помочь и хорошо известный список народов (алпидзуры, алцилдзуры, итимары, тункарсы, боиски), покоренный гуннами. Несмотря на то, что Иордан разместил эти народы в Северном Причерноморье [lord.Get., 126], а Прииск уже на Дунае [Prisc., 1], остается вероятность простого заимствования перечисленных имен готским историком из сочинения участника посольства к гуннам [10, с. 274, ком. 387]. Существует также мнение, что именно данные племена, возможно воспринимавшиеся современниками как собственно гунны, и составили основу группировки Ульдиса [12, с. 33]. При этом, исходя из анализа археологического материала к северу от Нижнего Дуная, М.М. Казанский делает вывод, что подавляющая часть гуннских находок здесь находилась в Южной Румынии, на территории Мунтении, Олтении и Валахии [12, с. 34]. Территория же Северной Молдовы с прилегающими районами, в это время, по-прежнему была занята готами и другими варварами, только с течением времени, интегрированными в гуннское объединение $[12$, с. 34-39]. Однако, судя по кладам позднеримских монет, которые справедливо считаются своеобразными маркерами военных походов гуннов [38, р. 206], завоевание данной территории началось не сразу. В этой связи, особенно выделяется север румынской Молдовы и Бессарабии, где концентрация находок позднеримских монет укладывается в хронологический диапазон 383-408 гг. [12, с. 42]. Нижняя дата этого диапазона явно указывает на осложнение отношений гуннов с местными варварами и римлянами, сразу же после заключения Феодосием договора с готами в 382 году.

Чтобы разобраться в данной проблеме, необходимо 
обратить внимание на то, что предоставление территории убежавшим от гуннов варварам, не могло не вызвать конфликт кочевников с империей. Поэтому, не исключено, что подчинение гуннами оседлого населения вблизи государственных границ, могло быть санкционировано римлянами и являться своеобразной компенсацией кочевникам за потерю значительной части своего зависимого земледельческого населения в ходе договора 382 года. Если это так, то именно с этого времени, Феодосий І устанавливает тесные отношения с основной массой гуннов, кочевавших в Северном Причерноморье и в прилегающих районах. Тем самым императору, возможно, удалось найти компромисс, не только с готами, но и с их новыми хозяевами, создав силовой противовес варварам Паннонии, за которыми определенно стоял Грациан. Конечно, сомнительно, чтобы гуннов устроило именно такое положение дел, и они окончательно смирились с гото-римским договором 382 года, лишившим их значительной части земледельцев. Скорее всего, со стороны римлян, здесь были даны обещания, что все ушедшие на территорию Римской империи варвары, со временем, будут вытеснены обратно в Барбарикум. В противном случае, если не принять такое допущение, трудно будет разобраться в дальнейших событиях, приведших к гунно-римской войне 395 года.

При этом, как обычно бывает в таких случаях, римляне предприняли все возможное, для того, чтобы не дать гуннам соединиться в одну мощную силу. Поэтому, в то время, когда с европейскими или западными гуннами были налажены отношения в районах Дунайского лимеса, то основные контакты римлян с восточными кочевниками происходили в боспорском Танаисе. Именно через этот возрожденный город, где в это время даже было возведено новое общественное здание [30, с. 310], гуннам - акацирам доставлялось определенное количество продовольственных товаров, а возможно в обратном направлении, была налажена поставка некоторых продуктов (рыболовства?) в империю и на Боспор. На существование такого товарообмена указывает обилие в слоях позднеантичного Танаиса импортной керамики (особенно амфор и краснолаковой посуды), а также завалы чешуи и костей рыб. К этому следует добавить и то, что в отличие от собственно Боспора, здесь, в этом восточном торговом центре гуннской державы, неожиданно обнаружено относительно много римской монеты, времени от Валента до Феодосия І, включительно (375395 гг.) [19, с. 174-202].

Учитывая отсутствие в данный период гуннских памятников в крымских степях и следов длительного противостояния кочевников с античными государствами, можно предположить о достаточно мирных или даже союзных отношениях римлян с западными гуннами и акацирами в раннегуннский период. Но в таком случае, можно допустить, что Феодосий I посредством нормализации отношений с гуннами и готами, решил вос- становить бывшую буферную зону Римской империи в Северном Причерноморье. Это тем более необходимо было сделать, так как после переселения части готов на территорию империи, собственно граница между римской цивилизацией и варварским миром оказалась размытой. В такой ситуации империю, от угрозы с востока, могли спасти лишь варварские союзники, которые были в состоянии остановить неприятеля еще на подходе к римским границам. Кроме того, императору предоставлялась возможность использовать военный потенциал кочевников против своих внутренних недругов и даже против готов - федератов, если те вновь подымут мятеж. Следовательно, при желании врагов Феодосия I ослабить его власть над восточной частью государства, им было необходимо разорвать установившиеся связи императора с варварскими союзниками.

Видимо именно такой тактике решил придерживаться узурпатор Магн Максим, когда в 383 году перешел с войсками из Британии в Галлию, убил императора Грациана и даже пытался захватить Италию. Понимая, что реальной угрозой его планам мог выступить только Феодосий I, он, судя по данным Зосима, подбил на выступление против него грейтунгов Одотея и присоединившихся к ним других варваров, подошедших к Дунаю из самых отдаленных мест [Zosim., IV, 35, 38, 39]. Так как достичь таких успехов Максим мог только через отправку своих эмиссаров в Северное Причерноморье, очевидно, что он обладал всей полнотой информации о ситуации в этой части античного мира. Учитывая, что после установления гуннской гегемонии в Северном Причерноморье, больше всего пострадали готы, следовательно, именно на них, в первую очередь, и мог рассчитывать Максим в своей борьбе с Феодосием І. Возможно, даже война грейтунгов за независимость от гуннов [33, с. 107-118], стала следствием подрывной деятельности эмиссаров британского узурпатора. Но если это так, то Максим, отправив своих людей в этот отдаленный от Западной Европы регион, просто не мог, не учесть в своих планах также и Боспор. Конечно, сложно предположить, какую сторону в этом предполагаемом конфликте, могли принять боспорские готы, а также собственно правители Боспора. Дело в том, что при Феодосии I, здесь, безусловно, продолжалась координация действий боспорских и римских властей со своими варварскими союзниками и в первую очередь, с гуннами - акацирами, что следует, хотя бы из анализа материала из Танаиса. Однако, в то же время, в среде боспорской элиты, просто не могли не сохраниться определенные антиримские настроения, в том числе и связанные с необходимостью возврата потерянных, в недалеком прошлом, территорий. Учитывая, что по сообщению Зосима, войско Одотея, напавшее на владения Феодосия I, состояло «из самых отдаленных и неизвестных племен» [Zosim., IV, 35], можно предположить, что эмиссары Максима добрались и до Боспора с прилегающими территориями, где со знанием дела использовали все накопившиеся противоречия в бо- 
споро-римских отношениях. Таким образом, решив использовать в борьбе за власть фактор недовольства политикой Константинополя частью населения Северного Причерноморья, Максим вряд ли мог обойти вниманием Боспор и варваров живших по периметру его границ.

К сожалению, почти полное отсутствие сведений на этот счет, не позволяет нам углубленно проработать данную тему. Единственным источником, подтверждающим косвенные сведения Зосима о возможной деятельности эмиссаров Максима в Северном Причерноморье, может являться находка здесь фрагмента римской воинской пряжки с рамкой в виде дельфинов [21, с. 65, табл. X, 7]. Несмотря на то, что фрагменты подобных типов портупейных пряжек известны, в том же Херсонесе [16, с. 98, рис. 5, 7; с. 100, рис. 6,7], обнаруженная Н.И. Репниковым вещь, достаточно резко выделяется из аналогичных находок. Как следует из записи, фрагмент пряжки происходил из инвентаря разрушенного погребения могильника Артек. Однако анализ этого предмета, проведенный А.Г. Фурасьевым, позволил усомниться в его местном производстве. Действительно, пряжек в виде дельфинов, найдено очень много на территории Британии, Франции, Германии, Австрии, Бельгии, в основном вдоль бывших границ Римской империи в районах британского, рейнского и дунайского лимесов. Однако слишком реалистическая передача фигур дельфинов объединяет пряжку из Крыма именно с оригинальными галльскими вещами и некоторыми их репликами из Британии. Подобные пряжки найденные вдоль дунайской границы, имеют более схематичный характер [27, с. 236-237].

При этом удивляет то, что пряжка с дельфинами, которая не может быть датирована временем позднее, чем начало V в. н.э., обнаружена среди инвентаря более позднего захоронения. Вероятно, данная вещь случайно попала из другого разрушенного единичного погребения второй половины IV - начала V вв. н.э. [27, с. 237]. Считается, что предметом торговли или обмена такие пряжки служить не могли, а их распространение обычно связывают с передислокацией легионов [27, с. 236]. Следовательно, учитывая уникальность нашей находки, можно предположить, что появление данной пряжки в Северном Причерноморье, было связано с какой-то разовой акцией западно-римского командования в достаточно удаленном от Западной Европы, регионе. Из всех наших источников, только Зосим косвенно свидетельствует о переходе готов и других варваров Северного Причерноморья на сторону Максима, после утверждения последнего в Галлии. Достичь такого успеха, как мы уже говорили, без деятельности специально посланных в регион эмиссаров, невозможно. Но если пряжка действительно принадлежала одному из участников посольства узурпатора, то тогда получается, что гибель его, по каким-то причинам, произошла не на готской территории, а на полуострове, в районе бывшей границы Боспора и Херсонеса [32, с. 185], где и была обнаружена.
Все это, может быть, совсем не случайно. Если эмиссары Максима имели отношение к выступлению готов против гуннского владычества, то с тем же успехом они могли спровоцировать и начавшиеся волнения на Боспоре, о которых нам практически ничего не известно.

Период дестабилизации на Боспоре конца IV в. н.э., известный исключительно по археологическим источникам, обычно связывается с внезапным нападением гуннов [39, р. 230], или какими-то внутренними событиями на Боспоре, вызванными нашествием неприятеля [4, с. 167]. При этом достаточно странная избирательность данного нападения, однозначно свидетельствует против обычного грабительского гуннского нападения, в пользу внутренних причин военных действий, развернувшихся на Боспоре. Так, приблизительно в конце IV в. н.э. жестокому разгрому подверглась Фанагория [15, с. 30 ], а к примеру, Гермонасса, или Ильичевское городище [18, с. 172-175], смогли избежать подобной участи [20, с. 178]. Напомним, что в свое время, многие подобные следы разрушений на Боспоре позднеантичного времени, после тщательного исследования, были радикально передатированы с конца IV на VI в. н.э. [22, с. 58-59; 23, с. 41-60]. Все это, разумеется, усилило интерес к событиям разрушений в Фанагории, тем более что, судя по анализу угля из слоя пожара на С14, который дал дату 250-390 гг. [4, с. 167], нападение на город, вполне могло произойти еще до гунно-римской войны 395 года.

По нашему мнению, один из ответов на загадку нападения на Боспор в конце IV в. н.э., необходимо искать в специфике этнического состава населения позднеантичной Фанагории. Именно в данный период здесь наблюдается сложный процесс интеграции эллинов и варваров. При этом помимо погребений с сарматскими чертами и смешанным греко-сарматским погребальным обрядом [17, с. 43], в Фанагории довольно четко фиксируется и восточногерманский культурный компонент [11, с. 277-297; 13, с. 171; 17, с. 43]. Более того, находки деталей ременной гарнитуры, и в особенности пряжек, характерных для германского культурного компонента и хорошо известных на позднечерняховских памятниках [24, с. 304-306], обычно связывается учеными с миграцией в конце IV в. н.э. черняховского населения, спасающегося от гуннской угрозы [42, s. 211-212]. Другими словами, в районе Фанагории, в свое время, явно была расселена часть готов, ушедшая от победивших их гуннов. Возможно, именно по этой причине, этот античный город и подвергся нападению кочевников. Следовательно, на Боспоре, как и на территории черняховской культуры, также мог произойти конфликт между гуннами и готами, в глубинной основе которого лежало стремление последних освободиться от власти кочевников. При этом за каждой из варварских групп могли стоять определенные римские и боспорские политические силы, что превращает, на первый взгляд, незначительное военное столкновение на далекой северной периферии поздне- 
античного мира, в ключевой конфликт в черноморском регионе раннегуннского времени. В пользу предположения, что основной причиной разгрома Фанагории, являлась борьба за власть на Боспоре, свидетельствует, выявленный, по другую сторону пролива, в предместье столицы у подножия горы Митридат, рядом со зданием музея, слой разрушений конца IV в. н.э. [3, с. 103-104]. Если допустить, что все данные следы дестабилизации ситуации в государстве, отражают попытку захвата власти и переориентацию политического курса Боспора на запад, в связи с установившимися отношениями с Магном Максимом и переходом на его сторону части боспорской элиты, то очевидно, что именно в это время боспоряне, вполне могли попытаться вернуть утраченные территории в Центральном Крыму.

Любопытно но, судя по археологическим данным, в конце IV в. н.э. в Юго-Западном и Центральном Крыму, действительно произошли неординарные события, которые привели к сильному сокращению населения на этой территории. Обычно данный уход людей связывают с неожиданным вторжением гуннов на полуостров [26, с. 145-147] и поэтому вынужденным переселением оставшегося населения в горные районы Крыма [1, с. 82]. Однако, несколько измененный состав погребального инвентаря новых могильников, а также появление в захоронениях многочисленных вещей аланского происхождения, имеющих аналоги на памятниках Северного Кавказа и Боспора [2, с. 274-311], свидетельствуют о более сложных процессах в регионе, чем простое переселение автохтонного населения на новое место $[28$, с. 479-480]. Чтобы разобраться в этом сложном вопросе, обратим внимание, что исходя из полного прекращения функционирования могильников Нейзац, Дружное и Перевальное в Предгорном Крыму в конце IV в. н.э., следует, что больше всего в ходе указанных событий, пострадала именно бывшая территория Боспорского царства. В долинах прилегающих к Херсонесу, также перестали хоронить на некоторых могильниках и уменьшилось население, однако, в целом городу удалось сохранить свое варварское окружение [1, с. 82; 26, с. 145-147]. Не исключено, что прекращение функционирования могильников в Предгорном Крыму, явилось результатом военных действий, которые вели здесь боспоряне и некоторые из боспорских готов, возможно, стремящиеся получить земли на завоеванных территориях. Им, очевидно, противостояли, варварские отряды Херсонеса, боспорские силы, выступающие за тесные отношения с Константинополем, гунны и их союзники аланы, включая аланских наемников с Северного Кавказа, которые видимо и навели порядок на полуострове, подавив, опасный для Феодосия I, мятеж. В этом случае, всем желающим, также могли быть обещаны земли из состава возвращенных земель. Скорее всего, именно данным обстоятельством, объясняется специфика погребального инвентаря новых варварских могильников горного Крыма. Также, возможно, что именно тогда была разгромлена Фанагория, как место дислокации мятежных готов и на территории Крыма погиб один из посланников Максима, пряжку которого и обнаружили в Артеке. Конечным итогом всех этих событий стал, как верно подметил С.В. Ушаков, уход многих варваров в Европу [26, с. 147], только, скорее всего, не с победившими гуннами, а с Одотеем, в составе его многочисленного воинства. Сейчас трудно сказать, какова же была основная задача этой варварской армии, пытающейся с боем прорваться на территорию Восточной Римской империи. Именно после пленения, оставшихся в живых данных варваров, происходивших, в том числе из «самых отдаленных и неизвестных племен» [Zosim., IV, 35, 1], «Феодосий, пораженный числом пленных и весом трофеев, освободил захваченных и раздал им дары в надежде, что, видя его доброту, они станут на его сторону, понимая, что бороться за Максима бессмысленно» [Zosim., IV, 39, 5].

Правда, не совсем ясной тогда представляется степень заинтересованности гуннов в данной войне, ведь вряд ли, они горели желанием превратиться в оседлых земледельцев. Чтобы разобраться в этом вопросе, необходимо учесть, что в 80-х гг. IV в. н.э. продолжал действовать запрет на эксплуатацию гуннами Крымских степей, даже если их использование было возможно, только в виде сезонных перекочевок [6, с. 61]. Напомним, что реакция римлян на данное событие, последует только через десятилетие. Таким образом, допуская помощь гуннов в преодолении мятежа на Боспоре, не совсем понятной выглядит конкретная выгода кочевников от участия во всех этих событиях.

К сожалению, у нас нет письменных источников, сведения которых могут подтвердить изложенную версию произошедших событий. Тем не менее, по нашему мнению, стоит обратить внимание на обстоятельное исследование В.П. Яйленко, посвященное присутствию гуннов на Боспоре в первых веках нашей эры [31, с. 303-331]. Особенно важной представляется интерпретация ученым известной надписи на мраморной плите, обнаруженной в Керчи еще в 1888 году, но которая до сих пор продолжает вызывать многочисленные споры среди исследователей. К сожалению, текст надписи сохранился не полностью, но даже в таком фрагментарном виде, безусловно, является ключевым источником информации о Боспоре позднеантичного времени. В издании КБН, с поправкой С.Р. Тохтасьева имени комита, надпись гласит: «В добрый час. При царе Тиберии Юлии Дуптуне благочестивом, друге цезаря и друге римлян, воздвигнута эта башня при епархе Исгудии и комите Спадине, заведующем пинакидой, и при первенствующем (?)..., сыне Сеавага, и при попечителе (?) работы ... месяца Горпиея ...» [КБН, 67] [8, С. 234]. По справедливому замечанию В.П. Яйленко, отсутствие в местном антропонимиконе имен царя Дуптуна и его ближайших сановников, свидетельствует о произошедшей этнической смене правящей верхушки государства. При этом, имена Дуптун, Исгуди 
и Саваг хорошо разъясняются именно на тюркском материале, и, следовательно, вполне могут иметь гуннское происхождение. Такому выводу трудно возразить, учитывая, что двухчастная структура и вторая часть имени Дуптуна, полностью соответствует данным особенностям более поздних имен гунно-булгарских ханов и родов. Все это однозначно свидетельствует о материальном единстве, таких имен, как Дуптун, Гостунъ, Вихтунъ, Дукум. В этом случае, содержание имени Дуптуна будет означать «имеющий (дикую) лошадку» [31, с. 324].

Сама же надпись, безусловно, отражает серьезную реорганизацию государственного управления Боспорского царства в позднеантичное время. Это привело к введению в штатный перечень, ранее не известных государственных должностей - префекта (в греческой терминологии епарх) и комита (в реконструкции Н.И. Храпунова - протокомита (главы сельского округа) [29, с. 88-90]). Однако данная реорганизация сопровождалась тем, что на все верховные должности были поставлены гунны (Дуптун, Исгуди, Саваг), должность же комита (протокомита) продолжал занимать алан Спадин. Очевидно, также, что титулатура Дуптуна была присвоена законно, скорее всего, посредством династического брака нового царя с правящим домом Боспора [31, с. 325-326]. Конечно, данная реформа государственного управления могла быть проведена еще до появления гуннов, однако мы согласны с В.П. Яйленко, что при современном состоянии источников, будет вернее предположить, что такая реорганизация все же была связана с событиями наступившей гуннской эпохи [31, с. 326]. Правда, вряд ли, она имела отношение к самому раннему периоду появления гуннов в Северном Причерноморье. Несмотря на то, что интеграция в античное общество на Боспоре представителей гуннской элиты, как и других союзных варваров, скорее всего, началась еще до императора Феодосия I, сомнительно, что уже в то время было решено допустить знатных гуннов до верховной власти в государстве.

Сомнение вызывает и представление, что в надписи царя Дуптуна, речь шла о возведении новой башни обновленной оборонительной линии, по причине сократившейся территории города [37, s. 515]. Напротив, анализ текста позволяет сделать заключение, что в нем говорится, не о постройке новых, а о восстановлении старых укреплений [8, с. 235]. То есть, с большей долей вероятности, можно предположить о случившемся нападении, предшествующем восстановлению башни. В этой связи, было бы заманчиво связать данные военные действия, с событиями конца IV в. н.э., известным нам по слоям разрушений на Азиатском и Европейском Боспоре. Тем более, что указанное время точно соответствует одному из самых ранних возможных вариантов датировки надписи Дуптуна - 679 г. б.э. (383-384 г. н.э.) [7, с. 518]. Эта дата, предложенная еще Э. Миннзом [40, р. 610], действительно хорошо согласуется со временем появления Максима в Галлии в 383 году и началом его противостояния с Валентианом и Феодосием I, следствием которого, скорее всего, и стали события в Северном Причерноморье. В таком случае и реорганизация государственного управления Боспора с выдвижением на высокие должности знатных гуннов и аланов, могла являться своеобразной платой союзным варварам, за помощь в подавлении мятежа. Более того, такими беспрецедентными мерами по усилению акациров, римляне и боспоряне, безусловно, создавали сильный военно-политический противовес западным гуннам, что помимо сдерживающего фактора во время конфликта, могло сыграть свою решающую роль.

Таким образом, восстановленная Феодосием I буферная зона Римской империи в Северном Причерноморье, безусловно, стала главным фактором, способствующим преодолению возникшего в регионе кризиса. Именно опираясь на союзные варварские силы, императору удалось подавить мятеж и в конечном итоге, вытеснить перешедших на сторону Максима готов к дунайскому лимесу, где они и были окончательно разбиты. Тем не менее, по причине не полностью урегулированных отношений с гуннами, вся система северопричерноморской буферной зоны, продолжала оставаться крайне нестабильной. Лежащий в ее основе достигнутый компромисс с кочевниками, являлся лишь временной взаимной уступкой, и при неблагоприятном стечении обстоятельств, мог легко перейти в острый конфликт, что в принципе и показали дальнейшие события.

\section{ЛИТЕРАТУРА}

1. Айбабин А.И. Этническая история ранневизантийского Крыма. Симферополь: Дар, 1999. 350 с.

2. Айбабин А.И., Хайрединова Э.А. Ранние комплексы могильника у села Лучистое в Крыму // МАИЭТ. 1998. Вып. VI. С. 274-311.

3. Айбабин А.И., Хайрединова Э.А. Крымские готы страны Дори (середина III - VII в.). Симферополь: 000 «Антиква», 2017. 368 с.

4. Атавин А.Г. Краснолаковая керамика из Фанагории IV-VI вВ. н.э. // Боспорский сборник. 1993. №2. С. 149-171.

5. Бейсенов А.З., Торгоев А.И., Дуйсенбай Д.Б., Ахияров И.К. Курган с «усами» Атасу-2 // Поволжская археология. 2018. №3(25). С. 103-117.

6. Болгов Н.Н., Рябцева М.Л. Гунны и Боспор в V в. // Великие Евразийские миграции / Материалы международной научной конференции. Элиста: Изд-во Калмыцкого госуниверситета им. Б.Б.Городовикова, 2016. С. 61-65.

7. Болгов Н.Н., Зайцева И.В. Тиберий Юлий Дуптун - последний царь Боспора и политика императора Анастасия // МАИАСП. 2019. № 11. С. $517-526$.

8. Виноградов Ю.Г. Позднеантичный Боспор и ранняя Византия (В свете датированных боспорских надписей V века) // ВДИ. 1998. №1. С. $233-247$. 
9. Засецкая И.П. Культура кочевников южнорусских степей в гуннскую эпоху (IV-V вв.). СПб.: Эллипс, 1994. 221 с.

10. Иордан. 0 происхождении и деянии гетов (Getica) / Пер., вступ.ст., коммент. Е.Ч.Скржинской. СПб.: Алетейя, 2013. 512 c.

11. Казанский М.М. Готы на Боспоре Киммерийском // Сто лет черняховской культуре. Киев: ИА НАН Украины, 1999. С. $277-297$.

12. Казанский М.М. Вождеское захоронение гуннского времени в Концештах и его культурно-исторический контекст // Tractus Aevorum: эволюция социокультурных и политических пространств. 2014. Т.1. №1. С. 28-51.

13. Казанский М.М., Мастыкова А.В. Золотая гривна из Фанагории: о германцах на Боспоре Киммерийском в позднеримское время // Боспорские чтения. 2007. Вып. VIII. С. 169-177.

14. Казанский М.М., Мастыкова А.В. «Царские» гунны и акациры // Гунны, готы и сарматы между Волгой и Дунаем. СПб.: Факультет филологии и искусств С.-Петер. гос.ун-та, 2009. С. 114-126.

15. Кобылина М.М. Разрушения гуннов в Фанагории // Вопросы древней и средневековой археологии Восточной Европы / под ред. В.И. Козенковой. М.: Наука, 1978. С. 30.

16. Костромичев Д.А. Римское военное снаряжение из Херсонеса // МАИЭТ. 2006. Вып. ХІІ. С. 43-128.

17. Медведев А.П. Позднеантичный некрополь Фанагории (по материалам раскопок 2005 г.) // Вестник Воронежского государственного университета. Серия: История. Политология. Социология. 2011. №1. С. 32-45.

18. Николаева Э.Я. Боспор после гуннского нашествия: диссертация ... кандидата исторических наук: 07.00.06. М., 1984. 230 с.

19. Обломский А.М. Хронология поселения Танаис позднеантичного периода // Лесная и лесостепная зоны Восточной Европы в эпохи римских влияний и Великого переселения народов. Тула: Гос. музей-заповедник «Куликово поле», 2010. Ч. 1. С. 174-202.

20. Плетнева С.А. Кочевники южнорусских степей в эпоху средневековья (IV-XIII века). Воронеж: Изд-во Воронеж, гос. ун-та, 2003. 247 с.

21. Репников Н.И. Некоторые могильники области Крымских готов. Могильник Суук-Су // ИАК. 1906. Вып. 19. С. 1-80.

22. Сазанов А.В. Боспор и гунны // XV Крупновские чтения по археологии Северного Кавказа. Махачкала: Институт языка, литературы и искусства им. Г. Цадасы, 1988. С. 58-59.

23. Сазанов А.В. 0 хронологии Боспора ранневизантийского времени // СА. 1989. №4. С. 41-60.

24. Строков А.А. Ременные гарнитуры гуннской эпохи Азиатского Боспора // Боспорские исследования. 2009. Вып. XXI. С. 303-319.

25. Томпсон Э.А. Гунны. Грозные воины степей. М.: Центрполиграф, 2008. 256 с.

26. Ушаков С.В. Варвары горной Таврики на рубеже эпох: Этническая ситуация в Юго-Западном Крыму (III - середина VI вв. н.э.). Опыт реконструкции (Археологический альманах № 23). Донецк: «Донбасс», 2010. 180 с.

27. Фурасьев А.Г. Римская воинская пряжка из Артека // АСГЭ. 2015. Вып. 40. С. $232-239$.

28. Храпунов И.Н. Некоторые актуальные проблемы истории и археологии Предгорного Крыма в позднеантичное время // Боспорские чтения. 2009. Вып. Х. C. 478-481.

29. Храпунов Н.И. К дискуссии о «Надписи Дуптуна» // Боспорский феномен. СПб.: Изд-во Государственного Эрмитажа, 2002. Т.1. С. 88-90.

30. Шелов Д.Б. Танаис и Нижний Дон в первые века н.э. М.: Наука, 1972. 350 с.

31. Яйленко В.П. Гунно-булгары II-V ВВ. н.э. на Боспоре по данным эпиграфики и антропонимики // Древности Боспора. 2002. Вып. 5. С. $303-331$.

32. Ярцев С.В. Северное Причерноморье в римский период и проблема готской экспансии. Тула: Изд-во ТГПУ им. Л.Н.Толстого, 2014.356 с.

33. Ярцев С.В. Обстоятельства похода готов Одотея на Римскую империю // Кондаковские чтения VI. Античность - Византия - Древняя Русь. Белгород: Издво БелГУ, 2019. С. 107-118.

34. Ярцев С.В., Зубарев В.Г., Бутовский А.Ю. Греко-варварский Крым в период поздней античности (III-IV вВ. н.э.: от морских походов до битвы при Адрианополе). Тула: Изд-во ТГПУ им. Л.Н.Толстого, 2015. 544 с.

35. Anke B. Studien zur Reiternomadischen Kultur des 4. bis Jahrhunderts / Band 1: Text \& Karten, Band 2: Katalog (Beiträge zur Ur-und Frühgeschichte Mitteleuropas). Weissbach: Beier \& Beran, 1998. B.1.222 s. B.2.156 s.

36. Bona I. Les Huns: Le grand empire barbare d'Europe: IVe-Ve siècles. Paris: Errance, 2002. 239 p.

37. Gajdukevič V.F. Das Bosporanische Reich. B.; Amsterdam: Akademie Verlag, 1971. 604 s.

38. Kazanski M. Les Goths et les Huns. À propos des relations entre les Barbares sédentaires et les nomades // Archéologie médiévale. №22. 1992. P. $191-229$.

39. Kazanski M.M. The Sedentary Elite in the «Empire» of the Huns and its Impact on Material Civilization in Southern Russia during the Early Middle Ages (5 th. -7 th. Centuries AD) // Cultural Transformations and Interactions in Eastern Europe. Aldershot, 1993. P. 211-235.

40. Minns E. Scythians and Greeks. Cambridge: Biblo \& Tannen Booksellers \& Publishers, Incorporated, 1913. 720 p.

41. Ščukin M., Kazanski M. et Sharov 0. Des les Goths aux huns: Le nord de la mer noire au Bas - empire et a l,epoque des grandes migrations / Archaeological Studies on Late Antiquity and Early Medieval Europe (400-1000 A.D.): Monographs I. British Archaeological Reports International Series 1535. Oxford: John and Erica Hedges Ltd., 2006. 482 p.

42. Tejral J. Fremde Einflusse und kulturelle Veränderungen nördlich der mittleren Donau zu Beginn Völkerwanderungszeit // Archaologia Baltica. Peregriatio Gothica. Łódz, 1986. T. VII. S. 175-238.

43. Tejral J. Neue Aspekte der frühvölkerwanderungszeitlichen Chronologie im Mitteldonauraum // Neue Beiträge zur Erforschung der Spätantike im mittleren Donauraum. Brno, 1997. S. 321-392.

44. Zaseckaja I.P. Les Steppes pontiques à l'époque hunnique / J. Tejral, F. Pilet, M. Kazanski (éds.) // L'Occident romain et l'Europe centrale au début de l'époque des Grandes Migrations («Spisy Archeologického ústavu av čr Brno», 13). Brno, 1999. P. 341-356. 